\title{
A BLOCKCHAIN TECHNOLOGY PROPOSAL FOR INFORMATION FLOW MANAGEMENT IN CIVIL CONSTRUCTION WORKS
}

\author{
Mário Augusto Santana de Oliveira Júniora, Herman A. Lepikson, Dr. Eng. ${ }^{b}$, Antonio \\ Ferreira de Oliveira Neto ${ }^{c}$ \\ a Programa de Pós-Graduação em Mecatrônica, UFBA; Salvador/Bahia, Brazil, \\ mario augusto@outlook.com \\ b Programa de Pós-Graduação em Gestão e Tecnologia, Senai Cimatec; \\ Salvador/Bahia, Brazil, Herman.Lepikson@fieb.org.br \\ c Programa de Pós-Graduação em Mecatrônica, UFBA; Salvador/Bahia, Brazil, \\ antoniofon14@gmail.com
}

\begin{abstract}
Civil construction faces major problems related to the traceability of its information flows, and among them, monitoring the progress of work in progress is one of the most critical. This is due to the limitations of the tools usually adopted in this industry. This article analyses the application of blockchain technology in the monitoring of construction works, aiming to develop a proposal that fills the gaps in the literature. The main works that implement blockchain technology in construction were selected to support the proposed approach. Finally, a proposal is presented in order to increase the confidence of information flows in civil construction.
\end{abstract}

Keywords: blockchain, BIM, civil construction, new technologies.

\section{UMA PROPOSTA DE TECNOLOGIA BLOCKCHAIN PARA GESTÃO DOS FLUXOS DE INFORMAÇÃO EM OBRAS DA CONSTRUÇÃO CIVIL}

Resumo: A construção civil enfrenta grandes problemas relacionados à rastreabilidade dos seus fluxos de informações, e dentre eles, o acompanhamento do progresso de obras em andamento se apresenta como um dos mais críticos. Isso ocorre devido a limitações das ferramentas usualmente adotadas nesta indústria. Este artigo analisa a aplicação da tecnologia blockchain no acompanhamento de obras da construção civil, visando o desenvolvimento de uma proposta que preencha as lacunas presentes na literatura. Os principais trabalhos que implementam a tecnologia blockchain na construção civil foram selecionados para subsidiar a abordagem proposta. Por fim, uma proposta é apresentada visando elevar a confiança dos fluxos de informação na construção civil.

Palavras-Chave: blockchain e BIM, blockchain e construção civil, blockchain e novas tecnologias 


\section{INTRODUCTION}

The construction industry uses methods that are still very conservative to manage and report the stage of a construction. Such methods are, in general, based on systems supported by schedules and cost control, accounting and personnel payment using basic computer tools, which depend both on the information contained in the project and on the elements of the construction in progress. This information is entered manually by intermediaries responsible for making connection between what was planned in the project and what was done in the real world, often introducing insufficient, wrong or outdated data [1].

The use of these traditional methods in sharing information that involves building management negatively influences trust between those involved in the construction process [2]. It usually presents failures not only in the management of works, but also in internal controls, in addition to excessive bureaucracy and difficult interaction between the contracting party and the hired service [3].

One of the main problems faced in civil construction is related to the lack of trust in relation to the integrity of the information shared between those involved in the construction process, as well as the lack of records about the users who made alterations, modifications or shared this information during the construction process [4]. It is worth mentioning that $47 \%$ of builders are unaware of compliance programs associated with the transparency of the organizations [5].

In this situation, the application of technologies such as BIM (Building Information Modeling) and IoT (Internet of Things) could help to increase confidence in the information flow. Although the application of these new technologies can contribute to mitigate these problems, they still do not solve the gaps in the reliability of information processing in their methodologies [6]. In this sense, the use of technologies contained in the blockchain network can make the registration of information in construction sites more reliable and agile [7].

Blockchain technology can be defined as a distributed, decentralized ledger, with digital data spread across the global computer network (nodes) without the need to have an intermediary or organization controlling the network [8]. The ledger contains information regarding a chain of blocks, where each block has records of transactions carried out linked to the previous block. The blocks are accessible to any member of the network, but can only be changed by the holder of the private key responsible for the transaction [9].

The implementation of blockchain technology in civil construction can be valuable when applied to recording the information flows about services performed (for example, noting when a service is started and its completion), transparently tracking and documenting the entire cycle of life of the construction [10]. Thus, both the contracting party and the hired service have more control over services performed in the construction environment through smart contracts until the final payment stage [11].

Therefore, there is an opportunity to develop an architecture capable of raising the confidence of information flows in civil construction using blockchain technology. This architecture will be able to meet both traditional and emerging management models and will ensure that those involved in the construction process have relevant construction data in an efficient, reliable and transparent manner. 


\section{METHODOLOGY}

The search for technical and academic articles related to the application of blockchain technology related to the topic was carried out using the online databases Google Scholar, ScienceDirect, SciELO - Scientific Electronic Library Online and IEEE Xplorer Digital Library, using the search words "Blockchain and BIM", "Blockchain and civil construction" and "Blockchain and new technologies".

The first stage of the research aimed to refine the means of how the research would be found, inclusion and exclusion criteria, quality determination and analysis of the data obtained. It was considered not only the presence of key words, but also the relevance of abstracts in relation to the subject in question, targeting work published in the last 3 years that focused on the use of blockchain technology in civil construction and works that reported opportunities to integrate it with new technologies.

In a second stage, publications outside the context were eliminated from the selection and repeated references were excluded before delving into the reading of the selected texts. Table 1 lists the main articles that supported this research.

Table 1. List of selected bibliographies in the databases $(15 / 07 / 2020)$

\begin{tabular}{|c|c|c|c|}
\hline $\mathbf{N}^{\circ}$ of Paper & Author(s) & Year & Title \\
\hline [16] & Shojaei & 2020 & $\begin{array}{l}\text { An implementation of Smart Contracts by } \\
\text { Integrating BIM and Blockchain }\end{array}$ \\
\hline [2] & Di Giuda et al. & 2020 & $\begin{array}{c}\text { The Construction Contract Execution } \\
\text { Through the Integration of Blockchain } \\
\text { Technology }\end{array}$ \\
\hline [14] & Luo et al. & 2019 & $\begin{array}{l}\text { Construction Payment Automation through } \\
\text { Smart Contract-based Blockchain Framework }\end{array}$ \\
\hline [15] & Tezel et al. & 2019 & $\begin{array}{l}\text { Preparing Construction Supply Chains for } \\
\text { Blockchain: An Exploratory Analysis }\end{array}$ \\
\hline [8] & $\begin{array}{l}\text { Nawari, } \\
\text { Ravindran }\end{array}$ & 2019 & $\begin{array}{l}\text { Blockchain technology and BIM process: } \\
\text { review and potential applications }\end{array}$ \\
\hline [12] & Hultgren, Pajala & 2018 & $\begin{array}{l}\text { Blockchain technology in the Construction } \\
\text { industry }\end{array}$ \\
\hline [13] & Gabert & 2018 & $\begin{array}{l}\text { Blockchain and smart contracts in the } \\
\text { Swedish construction industry }\end{array}$ \\
\hline
\end{tabular}

\section{RESULTS AND DISCUSSION}

It is observed that there is a relevant number of studies in recent years, including the current year, as shown in table 2 . 
Table 2. Amount of selected bibliographies per database (15/07/2020)

\begin{tabular}{|c|c|c|c|c|c|c|c|}
\hline \multirow{2}{*}{ Database } & \multicolumn{7}{|c|}{$N^{\circ}$ of Paper } \\
\cline { 2 - 8 } & 2014 & 2015 & 2016 & 2017 & 2018 & 2019 & 2020 \\
\hline Google Scholar & 0 & 0 & 0 & 1 & 6 & 8 & 12 \\
\hline ScienceDirect & 0 & 0 & 0 & 3 & 7 & 10 & 23 \\
\hline SciELO & 0 & 0 & 0 & 0 & 1 & 2 & 2 \\
\hline IEEE & 0 & 0 & 0 & 0 & 0 & 1 & 1 \\
\hline Total & 0 & 0 & 0 & 4 & 14 & 21 & 38 \\
\hline
\end{tabular}

As shown in table 2, it was noticed that the theme is highly relevant, showing a great effort by the academic community to seek solutions to the problems faced in the construction industry in relation to the lack of confidence in the information flows.

\subsection{Discussion from Selected Papers}

Hultgren, Pajala focused on applying blockchain technology to the wooden window supply chain between buyer and supplier in Sweden to help control deadlines on construction sites. The results found in the study confirm the ability to increase the transparency of the processes involved in the supply chain using blockchain technology. This is due to the fact that everyone involved can view and, when relevant, validate decisions and documentation inherent to the process. One difficulty encountered was in tracking the products. If a participant in the process needed to know his location at a certain point in the process, he would not have this information. A suggested solution would be to associate it with other technologies, such as RFID [12]

Gabert sought, in his dissertation, to reflect conceptually on the opportunities and challenges of the industry in relation to the application of smart contracts and BIM. It is worth mentioning that this publication highlights the lack of research carried out associating blockchain technology with the construction industry. The study reports how the civil construction environment is full of disputes and discussions, mostly related to payments and contract interpretations. As a result, two risks arise: moral and behavioral. Behavioral risk directly interferes with rules and personal interests in the progress of the project or payment [13].

In their article, Luo et al. report the difficulty in managing payments inherent to civil construction as it is characterized as a manual process and involves different parts of different hierarchical levels within each organization. In addition, there is a lack of clarity in the responsibilities and obligations between the parties involved. Based on that, they proposed a methodology to automate payments in civil construction from the use of smart contracts structured in blockchain technology [14]. 
According to Shojaei, a smart contract can be defined as a computational structure based on "If / Then" logic with the objective of managing contractual clauses between the entities participating in a business. When the execution of the contract is requested, the programming codes check the validity of the request. The system has numerous advantages such as faster and more reliable contract execution [16].

According to Tezel et al., the application of blockchain technology will increase trust between the interested parties in the process and facilitate collaboration, traceability and reduction of human error. However, the use of blockchain technology in civil construction enables new integrations. Data can be obtained through sensors, making information more reliable and interfacing the real and virtual worlds. In addition, both technologies, blockchain technology and sensors, can be integrated into the BIM model making the processes complete and reducing failures [15].

Nawari, Ravindran describes the problems faced with the authorization of new buildings after environmental disasters. The problem has no direct relationship with the traceability of contractual information flows, but envisions the integration between blockchain technology and the BIM model by automating projects through the upload of IFC files [10]. According to Eastman et al., the IFC (Industry Foundation Classes) is a specific data format that allows the exchange of information between BIM software that stores all the information for a given project. The objective here is to better integrate the project with the various stages of construction for certification [1].

Di Giuda et al. addresses a broad context about the integration of blockchain technology into the BIM model and highlights its application in the main stages of the construction process, from the elaboration of projects, tenders, execution of works to the maintenance of the product. The authors present relevant arguments about the use of smart contracts in tracking information flows and confirm that the integration of these technologies will allow a reliable management of the information obtained during the construction stage. However, the authors did not implement the commented approaches [2].

Shojaei reports the large number of legal disputes in civil construction due to the lack of compliance with terms present in the contract such as poorly performed or not performed services, as well as delays in payments and delays in carrying out workflows. Thus, the author sought to solve this problem by integrating the blockchain technology with the BIM model, focused on developing a secure link between the two technologies to make the system viable in order to track the flow of information, illustrated in the execution of a pillar in a building [16].

From the above, it is logical to conclude that the implementation of blockchain technology in the form of smart contracts with automatic or semi-automatic functions is an interesting alternative to reduce problems related to the traceability of information flows in civil construction. Also noteworthy is the possibility of integrating blockchain technology with other technologies such as BIM, RFID, IoT, drones, among others.

\subsection{Proposed architecture}

Figure 1 illustrates the conceptual architecture proposed in 3 stages, also showing how integration with other technologies such as BIM and loT takes place. 
Figure 1. Proposed architecture (source: author)

\section{CLIENT REQUIREMENTS FOR PROJECT ELABORATION}

CLIENT

金

\section{SUPERVISION OF WORKS USING BLOCKCHAIN}
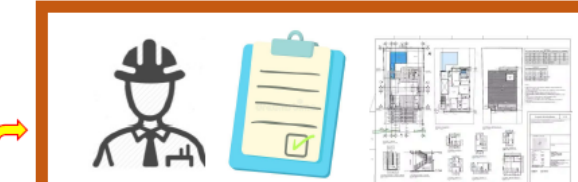

PRESENCIAL INPECTION + MANUAL DATA ENTRY
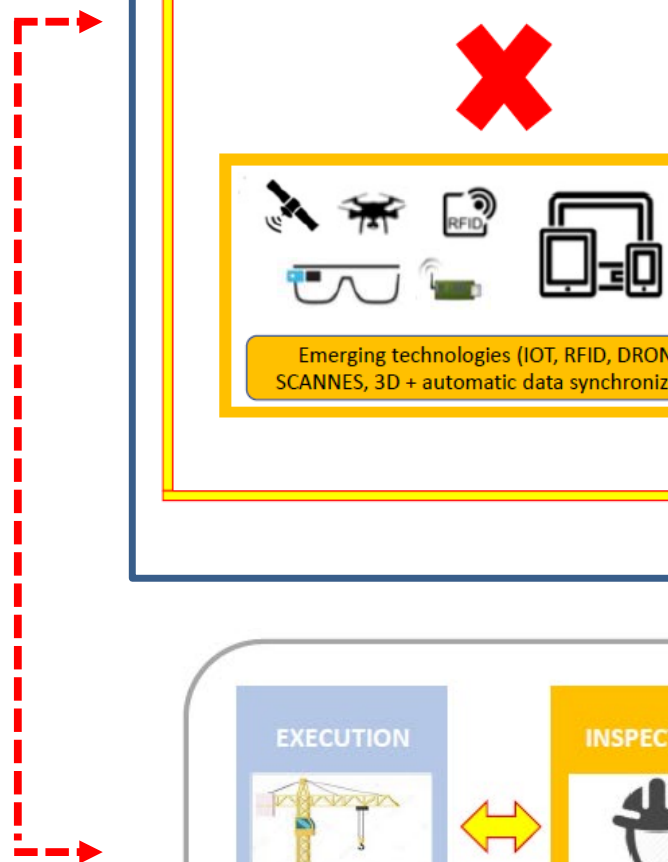

Emerging technologies (IOT, RFID, DRONES, SCANNES, 3D + automatic data synchronization)
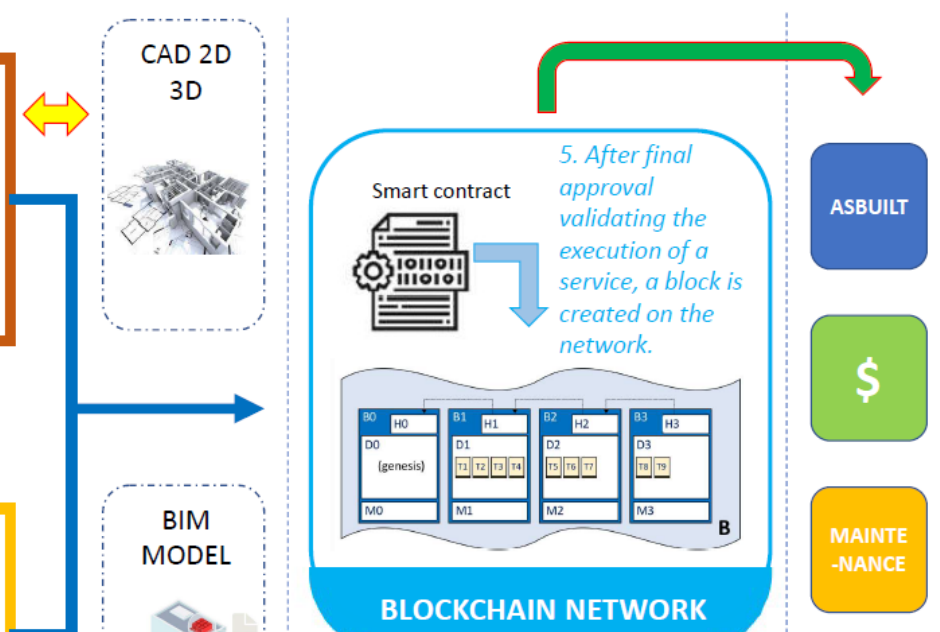

BLOCKCHAIN NETWORK
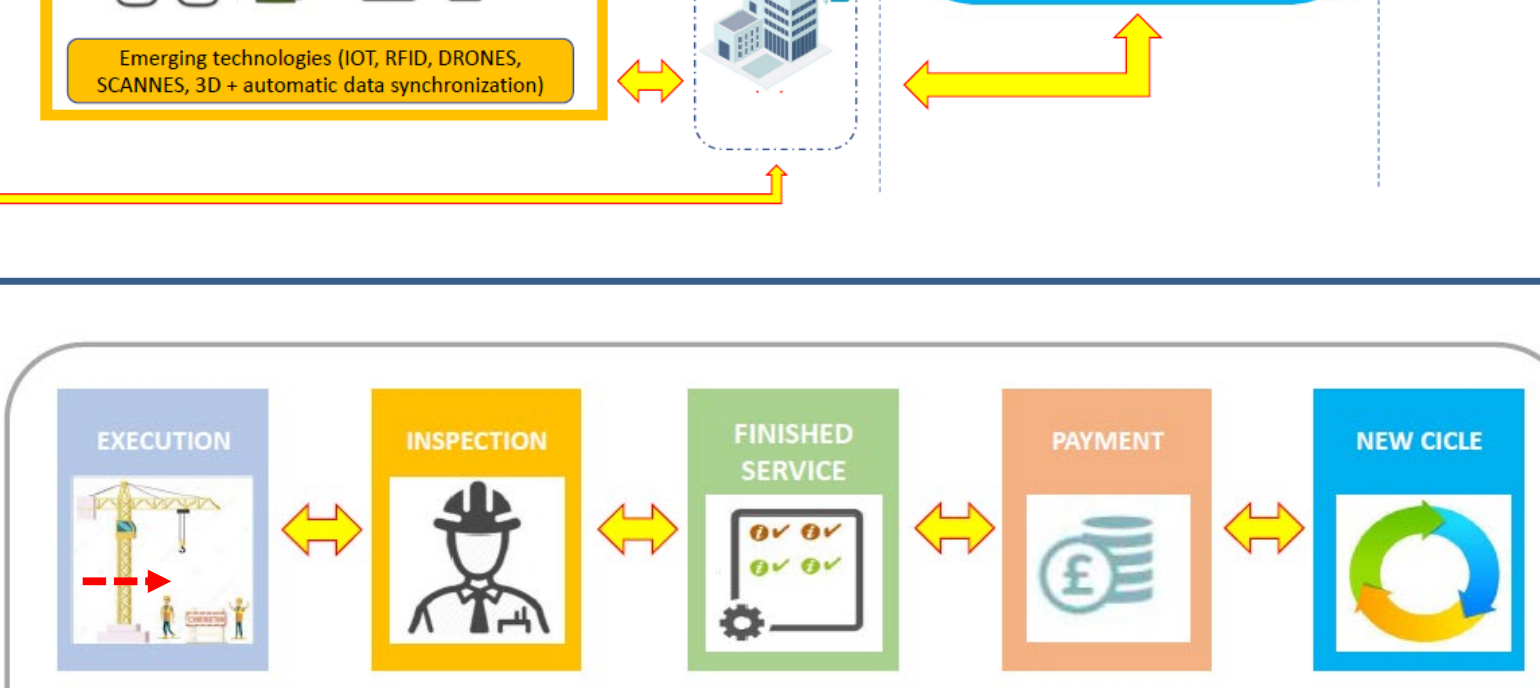

INFORMATION FLOW IN THE CONSTRUCTION PROCESS 
The main elements of the architecture shown in figure 1 are customer requirements, inspection of works and information flow during construction. Initially, the client requests the elaboration of a project to meet his needs. From the development of this project in CAD 2D, 3D or BIM platform, which includes the budget, planning and projects (architectural, electrical, hydraulic, structural, etc.), construction can begin.

When starting the execution of services, the inspection will act with the objective of guaranteeing that the client's requirements are met. The instant each service is completed, the executor will request that the inspection validate this request through the smart contract. The inspection process will be able to validate the service through face-to-face inspections with data insertion in the blockchain network or through emerging technologies such as loT, Rfid, drones that automatically fed smart contracts. It is worth mentioning that the integration with other technologies (BIM, loT, etc.) is not part of the scope of the initial work, but shows potential for future studies.

After validating the service, each inspector will validate the transaction through digital signatures, endorsing a transaction. Determine whether each validation sends a response and an endorsement to the smart contract application. Finally, a request is postponed, and a block is created on the network to track information flows. It is highlighted the potential use of blockchain technology to make payments on construction sites, carry out "As built" favoring the preparation of owner's manuals and maintenance services.

\section{CONCLUSION}

This work presented a blockchain-based architecture to increase the confidence of information flows in civil construction works. The architecture contemplates all the flows that involve a construction: project elaboration, inspection of construction sites with blockchain technology and validation of the client's requirements. The main contributions of this study are to demonstrate how blockchain technology can increase the confidence of information flows in civil construction from an architecture designed to meet face-to-face inspections with all the requirements present in smart contracts in the blockchain network.

The study is still under development as part of the author's master thesis and a broader project, aiming to implement this architecture to monitor the progress of construction sites. In future studies, it is intended to develop the integration of blockchain technology with BIM, IOT, Drones, 3D Scanner technology as demonstrated in the proposed architecture of this work to make the entire inspection process automated.

\section{REFERENCES}

${ }^{1}$ EASTMAN K. B.; TEICHOLZ, C.; SACKS, P.; LISTON, R. Manual do BIM: Um guia da modelagem da informação da construção para arquitetos, engenheiros, gerentes, construtores e incorporadores. 2014.

${ }^{2}$ DI GIUDA, G. M.; PATTINI, G.; SEGHEZZI, E.; SCHIEVANO, M.; PALEARI, F. The 
construction contract execution through the integration of blockchain technology. Research for Development, 2020, pp. 27-36.

3 CNI. Grandes obras paradas: como enfrentar o problema?. 2018. [Online]. Available: https://www.conjur.com.br/dl/estudo-cni-grandes-obras-paradas.pdf.

4 TURK, Ž.; KLINC, R. Potentials of Blockchain Technology for Construction Management. Procedia Eng., vol. 196, no. June, pp. 638-645, 2017.

5 KPMG CONSULTORIA. Pesquisa: maturidade do compliance no Brasil. In: Pesquisa sobre consolidação de Compliance no Brasil, p. 36, 2018.

${ }^{6}$ YE, Z.; YIN, M.; TANG, L.; JIANG; H. Cup-of-Water theory: A review on the interaction of BIM, IoT and blockchain during the whole building lifecycle. In: ISARC 2018 - 35th Int. Symp. Autom. Robot. Constr. Int. AEC/FM Hackathon Futur. Build. Things, no. July, 2018.

${ }^{7}$ ABLYAZOV, T.; PETROV, I. Influence of blockchain on development of interaction system of investment and construction activity participants. In: IOP Conference Series: Materials Science and Engineering, 2019, vol. 497, no. 1.

$8 \mathrm{~J}$. WANG, P. WU, X. WANG, and W. SHOU, "The outlook of blockchain technology for construction engineering management," Front. Eng. Manag., vol. 4, no. 1, p. 67, 2017.

9 S. A. Abeyratne, "Blockchain Ready Manufacturing Supply Chain Using Distributed Ledger," Int. J. Res. Eng. Technol., vol. 05, no. 09, pp. 1-10, 2016.

10 NAWARI, N. O.; RAVINDRAN, S. Blockchain and Building Information Modeling (BIM): Review and applications in post-disaster recovery, vol. 9, no. 6. 2019.

11 KASSEM, M.; LIA, J.; GREENWOOD, D. Blockchain in the built environment: analysing current applications and developing an emergent framework. In: Creative Construction Conference 2018 - Proceedings, 2018, pp. 59-66.

12 Hultgren, M.; Pajala, F. Blockchain technology in construction industry: Transparency and traceability in supply chain. p. 55, 2018.

13 GABERT, H. Blockchain and smart contracts in the Swedish construction industry: An interview study on smart contracts and services. 2018.

14 LUO, H.; DAS, M.; WANG, J.; CHENG, J. C. P. Construction Payment Automation through Smart Contract-based Blockchain Framework. 2019.

15 TEZEL, A.; PAPADONIKOLAKI, E.; YITMEN, I. Preparing Construction Supply Chains for Blockchain: An Exploratory Analysis. In: CIB World Build. Congr., no. June, pp. 17-21, 2019.

${ }^{16}$ SHOJAEI, A.; FLOOD, I.; MOUD, H. I.; HATAMI, M.; ZHANG, X. An Implementation of Smart Contracts by Integrating BIM and Blockchain. Advances in Intelligent Systems and Computing, vol. 1070. pp. 519-527, 2020. 